\title{
Digitalization of automotive industry - scenarios for future manufacturing
}

\author{
Steven Peters ${ }^{1, *}$, Jung-Hoon Chun ${ }^{2}$, and Gisela Lanza ${ }^{1}$ \\ 1 Institute of Production Science (wbk), Karlsruhe Institute of Technology (KIT), Karlsruhe, 76131 Germany \\ 2 Laboratory for Manufacturing and Productivity, Massachusetts Institute of Technology (MIT), Cambridge, MA, 02139 USA
}

Received 24 July 2015 / Accepted 6 November 2015

\begin{abstract}
Among the current challenges to the global automotive industry are changes in global markets leading to product variety, regulation leading to pressure for new technologies in body and powertrain, and competition by new players such as huge information and communication technology companies. Automotive original equipment manufacturers (OEMs) deal with these issues in different ways. This paper uses the scenario technique to illustrate possible answers to the question, how future value chains of automotive industry will look like. In almost all cases, information and communication technology (ICT) plays a major role in future strategies to cope with the aforementioned challenges. On the one hand, ICT can boost the way to more efficient production of variants by utilizing smart manufacturing approaches, on the other hand ICT enables new features such as autonomous driving.
\end{abstract}

Key words: Smart Manufacturing, Digitalization, Scenario Technique

\section{Motivation}

Globally, the automotive industry has sold more than 71 million cars in 2014, up 3.5\% compared to 2013 and the fifth record sales year in a row [1]. Nevertheless, the global automotive industry faces multiple challenges such as changes to the market, regulation, and the emergence of new competitors.

\subsection{Diversification of regionalized markets}

While most European automotive markets remain weak, the US market has recovered from crisis, the Chinese market is slowly growing [2], the Indian market is inconsistent, while Russian and South American market shares are decreasing [2]. Car companies try to succeed in promising markets by applying different global product and production strategies. For example, Volkswagen offers the VW Lavida exclusively for the Chinese market [3] and General Motors developed its brand Buick to successfully appeal to Chinese customers [4]. Some premium brands offer the same worldwide portfolio but have introduced long wheelbase derivatives (even for mid-size cars) and adjusted interior options to reflect regional preferences. Global markets and different customers' needs have led to a huge growth in automotive derivatives leading to complexity in manufacturing.

\footnotetext{
*Corresponding author: steven.sp.peters@outlook.com
}

\subsection{Strict and dynamic regulations}

By 2021 the average of the portfolio of an automotive original equipment manufacturer (OEM) has to stay below EU's limit of $95 \mathrm{~g} \mathrm{CO}_{2}$ emission per kilometer [5]. Similar regulations have been imposed in all major markets including China. In Elmau, Germany in June 2015, the G7 states agreed to a zero-carbon emissions economy by 2100 . However, car makers are already working very hard to stay below current emissions standards [6]. Besides the ongoing optimization of internal combustion engines, companies' R\&D activities focus on alternative powertrains like plug in-hybrids, battery electric vehicles and fuel-cells. Because of uncertainty of future regulations and customers' acceptance of the new technologies, flexibility in the existing car plants becomes crucial.

As important as the powertrain itself are improved aerodynamics and lightweight construction which are also influenced by emissions regulations leading to additional complexity in design, material and production phases. For example BMW has introduced a CFRP-intensive (CFRP = carbon fiber reinforced plastics) body in its BMW i3 (for details see [7] and for sales figures [8]), Ford uses aluminum in extensive ways [9] and several OEMs show complex multi-material-bodies. Again, the influences of those approaches on the production are significant. OEMs have to build up new know-how on processes and materials e.g. for the usage of CFRP [10] and multimaterial-bodies change the requirements of the used joining 
Table 1. Impacts of the challenges on car and production technology.

\begin{tabular}{|c|c|c|}
\hline Challenge & Impact on cars & Impact on automotive production \\
\hline Regulation & $\begin{array}{l}\text { Improved combustion engines; alternative (electric) } \\
\text { powertrains; advanced lightweight materials and multi- } \\
\text { material-approaches; improved aerodynamics; assistance } \\
\text { systems }\end{array}$ & $\begin{array}{l}\text { Micro-structured surfaces and micro-drilling; new } \\
\text { processes for manufacturing of batteries, fuel-cells; } \\
\text { joining of new materials and material-mixtures; } \\
\text { flexible approaches in body-in-white production }\end{array}$ \\
\hline ICT & Autonomous driving; connectivity in all dimensions & $\begin{array}{l}\text { Smart manufacturing/Industrie 4.0: scalable model- } \\
\text { mix-lines, operational excellence, assistance systems } \\
\text { for worker }\end{array}$ \\
\hline
\end{tabular}

technologies and thus leading to new approaches in the bodyin-white production and its automation. Those examples show how manufacturing has changed its role from restrictor to an enabler and how production related issues have to be integrated in the very early phase of design (compare [11]).

\subsection{New players and competitors from other industries}

The current content of electronics and software of a car is $35 \%$ ([2] referring on M. Broy, TU Munich) and electronics systems comprise of more than $90 \%$ of innovations and new features of cars [2] such as semiautonomous driving like automatic parking, lane-keeping assistance or sensor-based reporting [2]. Moreover, information and communication technology (ICT) becomes a crucial enabler for more efficient automation and operational excellence inside the manufacturing plants [12]. The authors call this ongoing rise of the importance of ICT in the automotive industry - in both products and production - the "digitalization" of the automotive industry.

Well-known ICT companies from Silicon Valley or China have been entering the car market. Today they are mainly partnering with the automotive OEMs in the fields of in-car infotainment $[13,14]$. In addition to those systems, Google has been testing its own self-driving car [15] and rumors about an Apple car have been circulating [16]. Recently there have even been speculations on a joint approach of Apple, BMW and Magna [17]. However, it is questionable whether the ICT giants are really going to enter the automotive OEM business which has a smaller profit margin compared to consumer electronics and Internet business. Regardless of the ultimate business model, ICTs will be a tremendous part of the value of any future premium car which could lead to tough competition, new alliances and business models among established automotive suppliers and the carmakers with ICT companies.

In addition, ICT approaches, namely the "Internet of Things" have become one of the strongest enablers for robust, flexible and efficient manufacturing especially when it comes to increased complexity and variety (compare Sects. 1.1 and 1.2). "Industrie 4.0" [12] or the Industrial Internet [18] is a major trend in worldwide manufacturing. Bosch even expects to achieve $30 \%$ efficiency increases by implementing Industrie 4.0 in their manufacturing [19]. With respect to the above mentioned challenges of different markets, customers, and technological complexity, Industrie 4.0 and its core technologies such as secure plug \& work-solutions for reconfigurations of machines, augmented reality based assistance devices for workers, cyber-physical systems with inexpensive sensors to automatically collect data in value streams, machines and components as well as machine learning and big data algorithms can be seen as enablers for car makers towards flexible automation, scalable model-mix-factories as well as a boost for the next step of operational excellence and lean production [20].

Table 1 shows the aforementioned challenges and collects their discussed impacts on cars and their production plants. These impacts have the potential to change the value chain of automotive industry in general, which will be analyzed in this paper. On the one hand side there is a need for innovation in almost all fields of the established car business e.g. in engines, in materials and in manufacturing and on the other hand, ICT companies become competitors and question the importance of these technological fields as well as the importance of own value creation. The later point is closely related to the scope of this paper.

\section{Literature review}

Before introducing and applying the methodology of scenario technique to illustrate potential pictures of the value chains of the future, a short literature review on the importance of an own value creation in established industries is given. The role of own manufacturing will be treated as a major influencing factor in the illustrated scenarios later on.

\subsection{Importance of the production depth in literature}

Decisions related to the question of which components or products a company should manufacture with own resources or buy on the market are called "make-or-buy"-decisions and are fundamentally important for a company as a whole [21]. More generally speaking, it is the strategic decision on the production depth of a company. The OECD defines the production depth of a nation as an "indicator [which] reflects the share of national production that is created in the country itself" [22]. Here, the production depth of a company (or of one of its products) is defined as the value added content created by a company itself (compare definition of Dürr [23]). Shifting parts of the value creation (or services) which have previously been done inside a company to external suppliers or partners is called outsourcing, while bringing it back is called "vertical integration" (or insourcing). 
There are multiple reasons for outsourcing and industrial cases have shown that it can be especially helpful in:

- reducing costs by outsourcing selected activities (catering services or production of parts of lower priority like normed screws) by benefitting from the suppliers' economies of scale,

- speeding up development by creating a close cooperation with specialists benefitting from the suppliers' economies of scope [24],

- enabling innovative features by cross-industry cooperation,

- reducing complexity inside the company and focus own limited resources on market-/brand- and quality-relevant components and features,

- fulfilling local-content requirements (regulated by governments),

- hedging against currency exchange rate fluctuations (by using suppliers in the corresponding regions),

- increasing flexibility (e.g. to keep job-shopper trained as capacity extenders in volatile markets).

Outsourcing has been a major topic since the 1980s [25] and consequently, a lot of research has been carried out to understand the complex influences it might have on a company's (long-term) performance. To get an overview of the focused issues, an analysis was done of the articles listed in Scopus. Figure 1 shows the breakdown of related articles by major effects: cost, innovation, flexibility and quality. Articles were counted which contain in their abstracts the term "outsourcing" and the terms "manufacturing" or "production" and in addition one of the four named effects: cost, quality, innovation and flexibility.

While well-known sources like Stuckey and White [26] warned companies only to vertically integrate "unless it is absolutely necessary to create or protect value", Lacity et al. found that empirical findings on outsourcing are conflicting [27]. Some authors identified negative relationships between outsourcing and indicators like market share when outsourcing reaches a level over a certain optimum [28]. Other studies showed that outsourcing really reduces operational costs [29]. Fuchs and Kirchain showed how wages, yields, downtimes and other parameters are dependent on the location of a factory and demonstrated that with real case data from the optoelectronics industry [30]. They discovered that a geographical separation of design activities and production is difficult in this innovative industry and potentially others using immature processes. Steven et al. presented an empirical study of links between outsourcing and product recalls, in which they used data from different industries and found outsourcing has a negative impact on quality performance, particularly in case of offshoring, outsourcing to a partner abroad [31].

From the perspective of the authors of this paper, literature and industrial cases both have proven that there are good reasons for outsourcing, but the more important the interlinkage between product and production gets, the more difficult it gets to find an optimal balance in terms of quality performance [31], speed to innovate or time-to-market [30, 32].

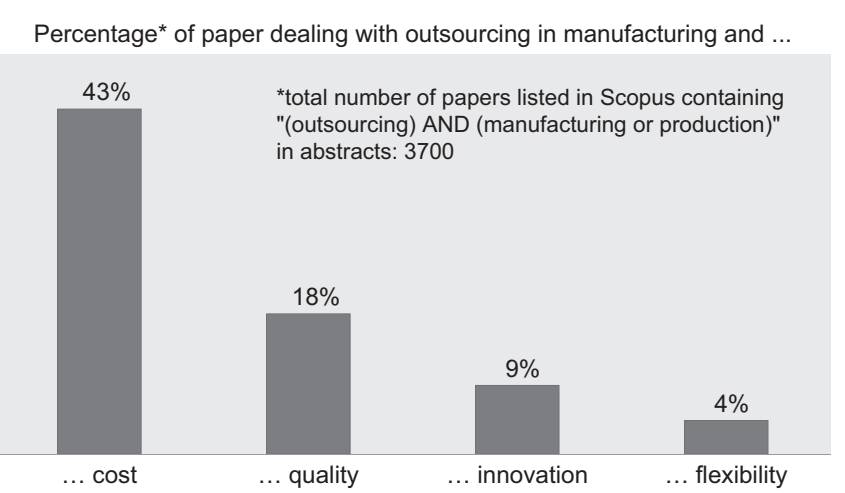

Figure 1. Overview of focused issues in outsourcing literature (data: Scopus).

\subsection{Fundamentals of scenario technique}

Scenario technique, e.g. implemented by Gausemeier et al. [33], is a well-established method to find feasible perceptions of the future in order to be able to prepare for it - either to avoid risks or to take advantage of chances [34]. It is an instrument used to think about the future in a structured way [33]. Therefore this method takes into consideration an understanding of influencing factors, collects their potential future realizations and finally combines them in multiple futures. Figure 2 illustrates scenario creation steps using Gausemeier et al.'s description. After defining the scenario base, also known as the decision field in its current situation, the methodology is as follows:

- Step 1: Scenario-Field Analysis. In this step, internal and external influencing factors of the decision field, such as that of an automotive OEM are collected using various methods. After brainstorming influencing factors they are filtered to gain a manageable amount of factors (e.g. below 20).

- Step 2: Scenario-Prognostic. For each remaining factor the potential future realizations are described. These projections should define a "window of opportunity" containing the most likely and most extreme scenarios.

- Step 3: Development Scenario. The obtained realizations are combined with each other leading to several thousand (due to combinatorics) "pictures" of the future. Eliminating those with contradictory assumptions and summarizing similar ones to clusters, leads to a manageable size of consistent pictures, which can be described into prosaic descriptions of the future.

\section{Scenarios for the future of automotive industry}

Selected core competences and current business model approaches of the automotive and the ICT industry are used to describe the effects "digitalization" may have on the automotive industry and their value chain. The focus is on premium 

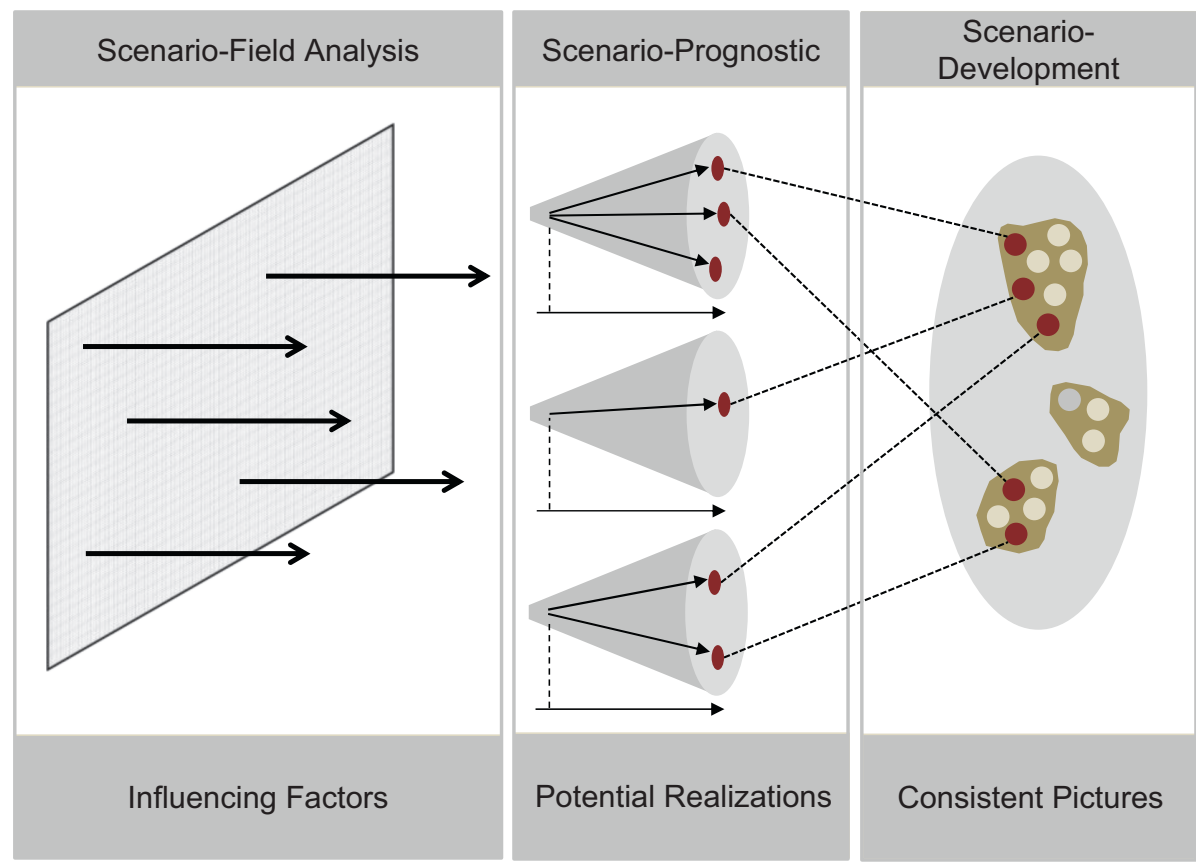

Figure 2. Process of scenario creation [33].

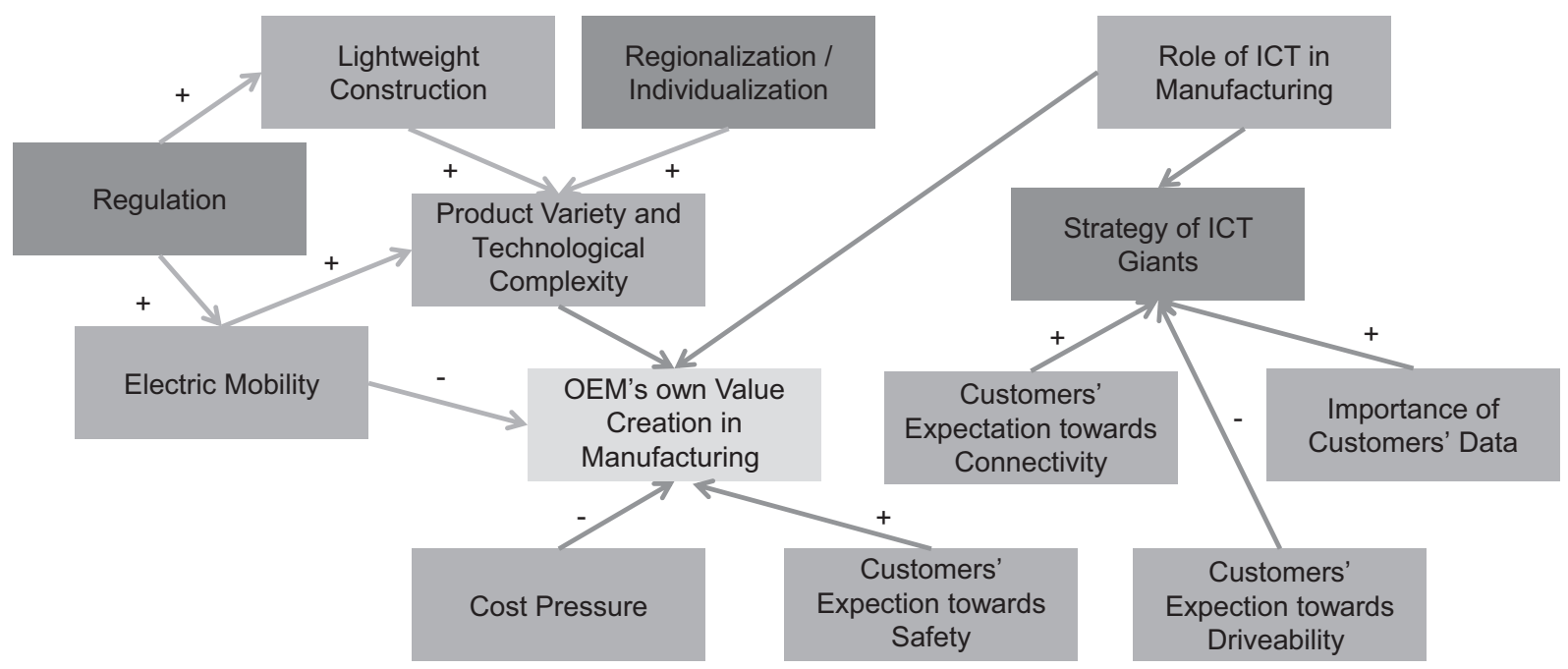

Figure 3. Influencing factors and their interdependencies.

automotive companies. This chapter is structured with Gausemeier et al.'s phases of scenario technique [35].

\subsection{Influencing factors}

Automotive OEMs' strategy towards their own value creation with respect to the automotive strategy of ICT giants is the core of this observation. Therefore, when identifying influencing factors, the current enablers of the business models of ICT giants in the new economy and today's exclusive core competencies of the automotive OEMs are observed at first. The former focuses on benefitting from (personalized) advertisements enabled by collected customer data [36, 37] and the later on holistic system knowledge leading to driveability, safety and quality. The term "quality" is used to describe a complex system like a car which is very reliable and has well-balanced characteristics. Figure 3 illustrates the collected factors and their potential interdependencies.

It is assumed that increasing cost pressure (alone) hints at decreasing own value creation of the OEMs. Product variety and technological complexity among others caused by the introduced aspects of shifts in markets, alternative powertrains and lightweight construction approaches influences the OEM's production depth, too - however, this influence is not necessarily heading into one clear direction. Some companies outsource to reduce complexity while others want to handle it internally expecting to gain synergies out of platform approaches more easily. In general it is assumed that electric 
Table 2. Influencing factors and potential realizations in the future.

\begin{tabular}{|c|c|c|c|}
\hline & Option 1 & Option 2 & Option 3 \\
\hline Cost pressure & $\begin{array}{l}\text { Increasing e.g. due to new } \\
\text { (global) competitors }\end{array}$ & As it is: high & $\begin{array}{l}\text { Decreasing due to higher } \\
\text { willingness to pay for } \\
\text { premium }\end{array}$ \\
\hline $\begin{array}{l}\text { Customers' expectation towards } \\
\text { driveability }\end{array}$ & $\begin{array}{l}\text { Increasing - even in developing } \\
\text { countries }\end{array}$ & $\begin{array}{l}\text { As it is: very high in developed } \\
\text { countries }\end{array}$ & Decreasing \\
\hline $\begin{array}{l}\text { Customers' expectation towards } \\
\text { connectivity }\end{array}$ & Main criterium & $\begin{array}{l}\text { As it is: one of the important } \\
\text { criteria }\end{array}$ & Just nice to have \\
\hline Strategy of ICT giants & Become automotive OEM & $\begin{array}{l}\text { Become major tier } 1 \text { system } \\
\text { supplier }\end{array}$ & Stay out of automotive business \\
\hline Importance of customers' data & $\begin{array}{l}\text { Very high: data is the money of } \\
\text { the } 21 \text { st century }\end{array}$ & $\begin{array}{l}\text { As it is: important mainly in the } \\
\text { new economy }\end{array}$ & $\begin{array}{l}\text { Low: e.g. reduced willingness to } \\
\text { pay with data }\end{array}$ \\
\hline
\end{tabular}

mobility leads to a decrease in production depth [38]. ICT companies strategies in the field of automotive are seen as dependent on the customers willingness to share their data which in turn is used for advertising and offering of new services. Moreover, their strategies are supposed to be affected also by customers' expectations towards driveability and (passive) crash safety of a future car - as fulfilling these requirements is usually seen as a major competence of the established automotive OEMs [17].

The role of ICT in manufacturing like the Industrial Internet affects strategies of automotive OEM and ICT companies. The effect of ICT in manufacturing is discussed from improvements in efficiency up to an enabler of simplification of manufacturing so that manufacturing knowledge might not be a crucial success factor anymore - in extreme terms: production might become commodity. However, in this analysis, companies offering ICT-solutions for manufacturing are seen as separated and decoupled from the ICT giants in the B2C-business (business to customer) which are potential candidates for entering the car market. Moreover, influencing factors like the value of brands, customers' psychology and the importance of styling are not covered by the analysis in this paper but have major impact on product development strategies of all players.

\subsection{Potential realizations}

In accordance with scenario technique, for each factor several options have been defined as potential realizations in the future as given in Table 2.

In order to manage the complexity of the data, some options were excluded such as the greyed out boxes in Table 2. Most of them are seen as unlikely, such as a decrease of cost pressure or variety (compare Sects. 1.1 and 1.2), while others were combined whenever they did not lead to significantly different implications (e.g. to the term "at least as high as today").

\subsection{Consistent pictures}

In the last phase, the remaining options were put together into four pictures describing a future industrial structure (Table 3). The major goal was to define consistent paths for ICT companies and automotive OEMs. It has been assumed that ICT companies are willing to become automotive OEMs only in those scenarios where customers' data has the utmost importance in their business models. One might argue that is not necessary to develop a whole car to collect customers' data, but, this approach assumes that the data sovereignty first and foremost stays with the manufacturer. All these assumptions may change as business models continue to develop, but seem consistent with today's perspectives and expectations. However, the value of customers' data might change suddenly e.g. in case of privacy violations followed by a loss of confidence by customers.

Picture 1 in Table 3 could be entitled "ICT companies overrule established automotive industry" and describes a state in which only some of today's automotive OEMs can survive. Due to "Industrie 4.0" production becomes commodity and almost anybody is able to manufacture a car. The survivors of the automotive industry will focus either on the design e.g. of specialized crash-structures for cars or become contract-manufacturers for the cars styled and sold by ICT companies.

The second picture is highlighted as "ICT companies become suppliers and competitors" and is a scenario, in which manufacturing knowledge remains important. Today's ICT companies become first tier system suppliers but might also conquer some specific markets (like urban cars) with own cars as well. However, the major goal of these companies in this scenario is to have direct access to the passengers inside the car during fully- or semi-autonomous driving to offer their medial content. Other ICT approaches like "Industrie 4.0" lead to significant increases of efficiency in manufacturing (but not to commoditization). However, companies with a significant 
Table 3. Consistent pictures of the future.

\begin{tabular}{|c|c|c|c|c|}
\hline & Picture 1 & Picture 2 & Picture 3 & Picture 4 \\
\hline $\begin{array}{l}\text { Customers' expectation } \\
\text { towards driveability }\end{array}$ & $\begin{array}{l}\text { Decreasing or high only in } \\
\text { some (developed) } \\
\text { markets }\end{array}$ & At least as high as today & Decreasing & At least as high as today \\
\hline $\begin{array}{l}\text { Importance of customers' } \\
\text { data }\end{array}$ & $\begin{array}{l}\text { Very high: data is the } \\
\text { money of the } 21 \text { st } \\
\text { century }\end{array}$ & $\begin{array}{l}\text { Very high: data is the } \\
\text { money of the } 21 \mathrm{st} \\
\text { century }\end{array}$ & As it is or lower & As it is or lower \\
\hline $\begin{array}{l}\text { Role of ICT in } \\
\text { manufacturing }\end{array}$ & $\begin{array}{l}\text { ICT makes production } \\
\text { commodity }\end{array}$ & $\begin{array}{l}\text { ICT boosts efficiency, but } \\
\text { does not make } \\
\text { production commodity }\end{array}$ & $\begin{array}{l}\text { ICT makes production } \\
\text { commodity }\end{array}$ & $\begin{array}{l}\text { ICT boosts efficiency, but } \\
\text { does not make } \\
\text { production commodity }\end{array}$ \\
\hline $\begin{array}{l}\text { OEM's own value creation } \\
\text { in manufacturing }\end{array}$ & $\begin{array}{l}\text { Decreasing by using } \\
\text { commodity to save } \\
\text { costs }\end{array}$ & $\begin{array}{l}\text { Increasing to gain } \\
\text { technology multiply } \\
\text { effect }\end{array}$ & $\begin{array}{l}\text { Decreasing by using } \\
\text { commodity to save } \\
\text { costs }\end{array}$ & As it is \\
\hline
\end{tabular}

amount of own value creation benefit from a deeper understanding and knowledge leading to faster ramp-ups of new cars and better quality. In this picture, automotive OEMs use these effects as well as their competences in term of driveability to further boost innovation, defend profit margins and to keep cars made by the ICT companies in niches.

Picture 3 is called "ICT companies become suppliers but define major product-differentiation" and describes again a situation in which almost anybody is able to manufacture a car in "Industrie 4.0". As customers expect high connectivity more than anything else, the diversification on the market is driven mainly by the ICT companies and their brands. That is why automotive OEMs focus on highly standardized, cost-efficient platform approaches. The ICT companies become tier 1 suppliers and gain the highest share of profit margins in the value chain. However, they do not see an additional potential by offering own cars themselves.

The last picture could be called "ICT companies stay outside the automotive business". It is based on advantages of ICT in terms of efficiency in manufacturing (e.g. by Industrie 4.0) but not in the car itself. That is why the established automotive OEMs are in a competition among each other but do not face new competitors from ICT.

\section{Implications on production depth}

The authors expect picture 2 to be most likely. In this section major aspects and reasons of this opinion are discussed starting with a view on ICT inside a car, followed by a statement on the importance of manufacturing know-how which seems to be supported by latest adjustments of OEM's production depths.

The business model of the ICT companies is based on collecting and managing customers' data in order to offer services and personalized advertising on a massive scale. It is quite obvious that there will be a huge potential for such business models interacting with the passengers when driving autonomously. From today's perspective it is very likely that the ICT companies with their infrastructure and methodology will try to take advantage of this. An open question is the data sovereignty and the business case for sharing customers' data between customer, automotive OEM and ICT companies.

As stated in Table 2, one potentially new role of ICT in manufacturing might lead to a commoditization of production by making operational excellence almost trivial when using the right ICT systems. In contrast to that, the second aspect of the discussion in this section focuses on an observation which is called "technology-multiplier" by the authors. This effect deals with new manufacturing technologies (compare Table 1) which cannot be substituted by any ICT solution. Its multiplying effect is based on the assumption that companies with a high share of their own value creation (deep production depth) are able to learn faster and as a consequence are able to innovate faster, to shorten the time-to-market and to develop and produce complex products with higher accuracy or at a lower cost. This assumption should not be generalized or misunderstood, as, when outsourcing components to suppliers - in the right selection and balance - there are proven potentials enabled by specialization and economies of scale among others, as stated in the literature review. However, there are some indications that (own) manufacturing in general seems to get more important:

- Production-Push-Approach: the view on manufacturing technologies has changed from a restrictor to an enabler of new product features. Examples of such enabling manufacturing technologies are laser technologies for micro-structuring of bearings, aluminum-aluminum resistance spot welding (RSW) in body-in-white manufacturing [39], additive manufacturing or resin transfer molding (RTM) to produce CFRP-parts [40] in series.

- Simultaneous Research: the mentioned complexity and variety of products as well as the fact that almost every new premium car requires at least one first-time application of a new manufacturing technology necessitate a close interaction between product design and production, and in doing so, a new dimension of simultaneous engineering is created [41]. 
Table 4. Synergies between Mobility 4.0 and Industrie 4.0.

\begin{tabular}{|c|c|c|}
\hline & Mobility 4.0 & Industrie 4.0 \\
\hline Data acquisition & $\begin{array}{l}\text { Innovative sensors inside and outside the vehicle } \\
\text { (Car-to-Infrastructure, Car-to-Car, etc.) }\end{array}$ & $\begin{array}{l}\text { Additional sensors in industrial equipment e.g. } \\
\text { machines and logistic systems or collected by a } \\
\text { human operator }\end{array}$ \\
\hline Data preparation/algorithms & In the vehicle & $\begin{array}{l}\text { In the machine control unit, in the factory or in } \\
\text { computers at the site of user or equipment builder } \\
\text { (e.g. via web communication) }\end{array}$ \\
\hline Enablers & $\begin{array}{l}\text { Advanced optical sensors, data fusion, online } \\
\text { evaluating systems, voice- and gesture control, } \\
\text { car-to-X-communication }\end{array}$ & $\begin{array}{l}\text { Physical sensors: temperature, vibration, current; } \\
\text { data fusion; voice control }\end{array}$ \\
\hline Business models & $\begin{array}{l}\text { Out-of-the-box approaches to use collected (big) } \\
\text { data recorded by the sensors in the cars in the field } \\
\text { (e.g. for traffic forecast) }\end{array}$ & $\begin{array}{l}\text { Improved services by gaining knowledge out of } \\
\text { decentral recorded data (e.g. robust Just-In-Time } \\
\text { deliveries, predictive maintenance) }\end{array}$ \\
\hline Impact on humans & $\begin{array}{l}\text { Increased freedom in a range from active } \\
\text { participation as a driver to passenger (in fully } \\
\text { automated driving mode) }\end{array}$ & $\begin{array}{l}\text { Expanded range of work content instead of } \\
\text { Taylorism - enabled by complexity reduction by } \\
\text { new assistance systems (e.g. digital Poka Yoke, } \\
\text { Human-Machine-Interactions) }\end{array}$ \\
\hline
\end{tabular}

- Point of Industrialization: to integrate a new manufacturing technology into series production (known as "industrialization") at the right time in terms of a balanced cost-benefit-ratio is of crucial importance [41, 42], being too late might lead to lost sales or lost cost savings but being too early might lead to increased costs due to the application of a pre-mature technology leading to higher scrap rates, lower speed or bad reliability.

Besides those suggestions made by the authors, there are some hints that OEMs might increase their own value creation. Already in 2007, BMW decided to increase their production depth which was at that time between $25 \%$ and $30 \%$ [43]. Recently, the importance of OEM's own value creation has been underlined impressively by Porsche AG: for approximately 20 years Porsche was famous for a very low production depth (e.g. 12\% for Porsche Cayenne [44]). But in early 2015 the company announced to increase its own value creation for at least the 10-20 most important parts related to quality or brand/image [45]. Japanese OEM, Toyota, itself has a quite low production depth but the depth of Toyota's company grouping ("Kairetsu") is about 76\% [46]. Similarly, Korea's Hyundai is also known for a high degree of value creation within the company grouping [47]. In 2012, Wyman forecasted an average global production depth of OEMs of $29 \%$ by the year 2025 [38].

\section{Additional implications}

Besides these findings on future value chains an aspect related to the question of gaining money out of the digitalization in products and production, should be discussed. Therefore, product and production shall not be treated as decoupled anymore. "Industrie 4.0" and autonomous driving (which could be called Mobility 4.0 in this analogy) use quite similar technologies such as various types of (optical) sensors, data fusion systems and decentralized decision making algorithms. Table 4 collects key enablers and potential approaches of Industrie 4.0 and Mobility 4.0. However, autonomous systems like automated guided vehicles in logistics, augmented reality solutions in technical services or condition monitoring systems for predictive maintenance in manufacturing plants are far behind the achievements of autonomous driving. Consequently there might be a chance for ICT companies in addressing both, cars and car factories, with their technologies and solutions in the future.

Today, the usage of advanced product life cycle management systems linked to manifold simulation tools and Big Data algorithms is state of the art during the product development of a car. However, the automotive development processes of today are still static and inspired by pre-defined quality gates. There might be a chance for even more efficient product development in the automotive industry by adapting ICT companies' agile development processes especially when facing volatile markets. Of course, the adaptation of agile methods to automotive has to ensure the same high-quality outcome of today's automotive processes. Successful approaches have already been presented in reference [48]. As a consequence ICT companies might be able to learn how to increase the robustness of their products without losing speed during development.

\section{Closing remarks}

This paper has presented potential outcomes of the current convergence of the old and new economy as represented by the automotive industry and ICT companies. Digitalization in terms of the rising importance of ICT in production and products might have a strong impact on the automotive industry. However, the authors expect that manufacturing will not become "commodity" as manufacturing knowledge not only leads to improvements in operational efficiency but also drives innovations in fields, which ICT solutions cannot cover, e.g. CFRP-intensive bodies. Therefore automotive OEMs should carefully adjust their own value creation and continuously assess where their individual optimum is - taking into account the ability to innovate quickly. Moreover, global customers' expectations in terms of driveability, quality and safety as well as their behavior towards sharing private data must be observed continuously and very carefully. 
Acknowledgements. Steven Peters is indebted to the BadenWürttemberg Stiftung for the financial support of this research project by the "Eliteprogramm für Postdocs".

\section{References}

1. Scotiabank (2015) http://www.gbm.scotiabank.com/English/ bns_econ/bns_auto.pdf

2. PricewaterhouseCoopers AG (PwC) (2015) http://www. strategyand.pwc.com/perspectives/2015-auto-trends

3. CarNewsChina (2013) http://www.carnewschina.com/tag/ volkswagen-lavida/page/2/

4. Business Insider (2013) http://www.businessinsider.com/ why-chinese-buyers-love-buick-2013-4? IR=T

5. European Commission (2015) http://ec.europa.eu/clima/ policies/transport/vehicles/cars/index_en.htm

6. Reuters (2014) http://www.reuters.com/article/2014/10/02/ autoshow-paris-carbon-idUSL6N0RX5S520141002

7. BMW AG (2013) http://www.bmwgroup.com/bmwgroup_prod/ d/0_0_www_bmwgroup_com/investor_relations/_pdf/ Workshop-Presenation_BMW_i_Innovation_Days.pdf

8. Automobil Produktion (2015) http://www.automobil-produktion. de/2015/06/bmw-seit-produktionsstart-3-500-i8-abgesetzt/

9. Ducker Worldwide LLC (2014) 2015 North American Light Vehicle Aluminum Content Study: Executive Summary. http:// www.alcoa.com/car_truck/en/pdf/2014_Ducker_Executive_ Summary.pdf

10. New Scientist, http://www.newscientist.com/roadtothefuture/ casestudy

11. G. Schuh, K. Korthals, J. Arnoscht, Advanced Materials Research 907 (2014) p. 329-347.

12. National Academy of Science and Engineering (achatech), Recommendations for implementing the strategic initiative INDUSTRIE 4.0, 2013

13. Volkswagen AG (2015) http://www.volkswagenag.com/content/vwcorp/info_center/de/news/2015/05/baidu.html

14. Daimler AG (2015) http://media.daimler.com/dcmedia/0-921658901-1-1678242-1-0-1-0-0-1-0-0-0-1-0-0-0-0-0.html? TS= 1435327318437

15. NBC News (2015) http://www.nbcnews.com/tech/innovation/ googles-self-driving-car-prototypes-hit-public-roads-first-timen381941

16. Macworld (2015) http://www.macworld.co.uk/news/apple/willapple-make-icar-rumour-roundup-3425394/

17. Süddeutsche Zeitung (2015) http://www.sueddeutsche.de/auto/ autoprojekt-icar-buendnispartner-fuer-apple-gesucht-1.2398276-3

18. Industrial Internet Consortium (2015) http://www.iiconsortium. org/vertical-markets/manufacturing.htm

19. Robert Bosch GmbH, 2015, http://www.bosch-presse.de/ presseforum/details.htm?txtID=7070\&tk_id=107

20. S. Peters, et al., Manufacturing Review 1 (2014) 10.

21. L.R. Jauch, H.K. Wilson, Long Range Planning 12 (1979) 06.

22. OECD, Measuring Globalisation: OECD Economic Globalisation Indicators 2010, OECD Publishing, 2010, p. 208
23. Dürr AG (2015) http://www.durr.com/investor/service-faqscontact/glossary/technical-glossary/manufacturing-depth/

24. M.E. Porter, Harvard Business Review 74 (1996) 06.

25. M.C.J. Caniels, A. Roeleveld, European Management Journal 27 (2009) 402-417.

26. J. Stuckey, D. White, Sloan Management Review 34 (1993) 71.

27. M.C. Lacity, et al., Journal of Information Technology 25 (2010) 04.

28. M. Kotabe, et al., Journal of the Academy of Marketing Science 40 (2012) 02.

29. B. Jiang, J.A. Belohlav, S.T. Young, Journal of Operations Management 25 (2007) 04.

30. E. Fuchs, R. Kirchain, Design for Location, Management Science 56 (2010) 12.

31. A.B. Steven, Y. Dong, T. Corsic, Journal of Operations Management 32 (2014) 05.

32. A. Gunasekaran, et al., International Journal of Production Economics 161 (2015) 153-166.

33. J. Gausemeier, A. Fink, O. Schlake, in Szenario-Management Planen und Führen mit Szenarien, Carl Hanser Verlag, München, 1995.

34. H. Bullinger, D. Spath, H. Warnecke, Handbuch Unternehmensorganisation - Strategien, Planung, Umsetzung, edited by E. Westkämper, 3rd edn., Springer-Verlag, Berlin/Heidelberg, 2009

35. J. Gausemeier, A. Fink, O. Schlake, Technological Forecasting and Social Change 59 (1998) 02.

36. Entrepreneurial Insights (2014) http://www.entrepreneurialinsights.com/google-business-model/

37. ZEIT (2013) http://www.zeit.de/2013/41/privatsphaere-internet-datenschutz/seite-2

38. Oliver Wyman, VDA, FAST 2025 - Massiver Wandel in der automobilen Wertschöpfungsstruktur, 2012

39. Automotive News (2015) http://www.autonews.com/article/ 20141124/OEM06/311249975/as-ford-spends-big-gm-joinsaluminum-with-simple-welds

40. CompositesWorld (2015) http://www.compositesworld.com/ blog/post/the-making-of-the-bmw-i3

41. S. Peters, International Journal of Production Research 53 (2014) 13.

42. S. Peters, wt Werkstattstechnik online 5 (2015).

43. Pressebox (2007) http://www.pressebox.de/pressemitteilung/ bmw-ag-0/BMW-will-in-diesem-Jahr-die-Produktivitaet-umzehn-Prozent-steigern/boxid/99347

44. Prognos, Die Veränderung der europäischen Wertschöpfungsstrukturen im Zuge der Vollendung des europäischen Binnenmarktes und der EU- Erweiterungen, 2007

45. Wirtschaftswoche (2015) http://www.wiwo.de/unternehmen/ auto/porsche-chef-matthias-mueller-das-apple-modell-istnicht-auf-uns-uebertragbar/11498816-2.html

46. INGENIEUR.de (2009) http://www.ingenieur.de/Branchen/ Fahrzeugbau/Innovationsfaehigkeit-wichtiger-Lohnkosten

47. Automobil Industrie (2012) http://www.automobil-industrie. vogel.de/oems/articles/367094/index3.html

48. Robert Bosch GmbH (2015) http://www.scrum-day.de/files/ scrum-day/content/upload/c4p-vortraege-2015/G1-VolkmarDenner_Keynote_Scrum_Day_Gn_150615.compressed.pdf

Cite this article as: Peters S, Chun J-H \& Lanza G: Digitalization of automotive industry - scenarios for future manufacturing. Manufacturing Rev. 2016, 3, 1 . 